\title{
MULTIPLE WIVES, CO-WIVES AND FEMALE STATUS: EXAMPLE ON CONTEMPORARY CHANGE FROM MANIPUR (INDIA)
}

\author{
Mayanglambam ManiBabu \\ Associate Professor, Anthropology, Department \\ Manipur University Imphal, India \\ E-mail:mmanibabu@yahoo.co.in
}

\section{Introduction}

A socially sanctioned marital relationship in which a man has more than one wife simultaneously is referred to as polygyny. And study on polygyny in the light of the relative statuses of the co-wives in the contemporary societies where this institution prevails, is of common interest of discussion to the anthropologists. This marital practice is probably the most common mating system among vertebrates, and especially common among mammals (Eisenberg, 1966). It is reported that about $91 \%$ of all bird species are monogamous (Lack, 1968) and the rest are polygamous (either polygynous or polyandrous) or promiscuous (Altmann, et al., 1977). Verner and Willson (1966) have reported that only 14 of 291 species of North American passerine birds (about $5 \%$ ) are either regularly polygynous (i.e. with $5 \%$ or more of the males polygynous) or promiscuous, with exceptional cases reported in 16 others. On the basis of the propositions of different workers, Stuart Altmann, et al. (1977) has reported four explanations for the evolution of polygyny among the animals, particularly the avian. The root of polygyny among the Homo sapiens sapiens, as proposed by Ralph Linton (1936:183) is from the general private urge to collect females. Among the 19th century evolutionary theorists, Engels (1985:74) comprehended that it occurred mainly in the middle ranges of the three societal complexities, that is, group marriage, polygynous marriage and monogamy. Engel's notion is, however, corroborated by the subsequent cross-culture researches (e.g. Osmond, 1965; Blumberg and Winch, 1972; Martin and Voorhies, 1979; Hartung, 1982; Alvard, 1986; etc.) viewed polygyny as a reproductive strategy (known as, r-strategy) by which men maximize the number of their offspring but minimize investment in each child, which obviously suggests that polygyny has more reproductive benefits for men than for women. Hartung (1982:5), among others, also favours this male-centered notion of polygyny. Ford and Beach (1951) found that $84 \%$ of the 185 cultures studied were permitted to have more than one wife at a time. Coult and Habenstein (I965) also reported that about 70 percent of the societies known to anthropology permit a man to be married to two or more women simultaneously. The prevalence of polygyny in many societies is seen to be related with many factors, such as economical, sociocultural, political, environmental, etc. Two kinds of the economic explanations for polygyny - one, based on household economics, and a second based on the degree of agricultural intensifications, are known (Boserup, 1970; Goody, 1976; Burton and Reitz, 1981). An economic model of polygyny, summarized by Grossbard $(1976,1980,1986)$ includes several postulations: 1$)$ As the value of women's subsistence contributions increases, polygyny becomes more likely, since the income that men gain from marriage increases; 2) As women's wage opportunities outside the domestic domain increase, polygyny decreases; 3) As inequality among men increases, polygyny increases, since women will choose and marry wealthy man who already has several wives. Further, wealthier men will be more likely to choose polygynous marriages ; 4) Homogamy decreases the incidence of polygyny by limiting the possibilities for polygynous marriages; 5) As the sex ratio decreases, polygyny will increase; 6) If there are economies of scale of polygynous households, polygyny is more likely. A number of workers (Murdock, 1949; Heath, 1958; Osmond, 1965; Lee, 1979; Burton and Rietz, 1981, etc) find positive relationship between polygyny and female 
economic contribution discerned at different subsistence levels. However, Goody (1973:189), rejecting the female contribution hypothesis, maintained that 'the reasons behind polygyny are sexual and reproductive rather than economic and productive'. He further contended that men marry polygynously to maximize their fertility and to obtain large households containing many young dependent males. White and Burton (1988: 871) flatly rejected this view of the relationship between satisfaction of male sexual appetites and polygyny. The disparity in the adult sex ratio caused by the external and internal factors - such as, male mortality from disease, warfare, dangerous occupation, male labour migration, and so on - has significant relations to the prevalence of polygyny in a society (Dorjahn, 1959; Whiting, 1977; Lee, 1979; Dow, 1983; Ember, 1974, 1984-85; etc.). Ember (1974) postulated that polygyny is a consequence of high male mortality in warfare, which reduces the sex ratio. An ethnographic example of adult sex ratio imbalances outlined by Beals, et al. (1977: 393) among the autocratic and monarchial Baganda of Uganda (East Africa) shows yet another unusual exogenous and endogenous factor of demographic processes which led the people to take up polygynous marriage -

The wide dispersal of polygyny among the Baganda was made possible by the high mortality rate among Baganda males. In chiefly families, male children were often killed at birth; the princes of the royal house, once the successor to the throne had been chosen, were put to death; the king arbitrarily killed off male retainers and servants who displeased him; males, never females, had to be sacrificed in great numbers to the gods at appropriate ceremonies; and great numbers of men were killed in the animal wars the Baganda collected with their neighbours. As a result of these factors, plus the fact that large numbers of women were taken as booty in war expeditions, the women outnumbered the men by three to one. It was this disparity in the relative numbers of men and women that made polygyny on so wide a scale possible.

Yet another explanation of causes of polygyny, which bears similar notion of sex ratio interpretation, is that of the late marriage of men than women (Ember, 1984-85). The argument, here, is that delaying the age of marriage for men would produce on artificial, though not actual, excess of marriageable women - thereby causing adult sex ratio disparity. Another argument of the development of polygyny, proposed by Whiting (I964), is that polygyny will develop in societies that prohibit the resumption of intercourse for a year or more after the birth of a child. Whiting's argument is that polygyny may be adopted all societies practicing a long post-partum sex taboo, in order to provide the husband with socially approved sexual partners. That is, the husband with a wife who is sexually tabooed to him for a year or more after the birth of a child will be likely so, Whiting assumes, to take another wife in order to continue sexual relations in a socially approved fashion. Whiting's proposition of a long post-partum sex taboo as a necessary consequence of polygyny was strongly react by Melvin. Ember (1974) who argued that -

Why should a husband, whose wife is sexually tabooed to him for a year or more, be obliged to take another wife in order to continue his sexual relations in a socially approved fashion? Why could not extra-marital affairs be socially approved (as we know they are in many societies)? Even assuming that such affairs would not be easy or safe to arrange, why could not the husband masturbate or even abstain from all sexual activity? (P.198).

Environmental bearings of polygyny were contended by Boserup (1970) and Verdon (1983), who saw general differences in the rates of polygyny between the forest and savannah adaptations. How polygyny affects reproductive processes of a population is also another area of concern to a number of social scientists. Regarding the effect of polygyny on reproductive behaviour - myriad viewpoints have been put forward by different workers, such as, that polygyny reduces the fertility of individual women (Garenne and van de Walle, 1989; Handwerker, 1986; Pison, 1987), that it has no effect at all (Mulder, 1989; Pebley and Mbugua, 1989; Sichona, 1992), and that it increases women's fertility (Ahmed, 1986; Arowolo, 1981).

Besides determining the social status of a person concerned through his possession of a number of wives, the rule of polygyny obviously exerts myriad impacts on the relative statuses of the females, 
the co-wives of a polygynist - manifesting varied sub statuses and sub roles in consonance with the respective socio-cultural settings. Here lies the special pursuit of deliberation among the social scientists since this aspect, rather, deviates from the general outlook of the relative status of women to gender disparity. Here the problem is not primarily between males and females but between the principal wife and co-wives, and amongst the co-wives of a polygynist on how much power and authority the first wife or the other wives have relatively to each other and their respective roles in a polygynous plural family. In this context, one needs to look for a relevancy of Martin Whyte's (1978) notion of female 'status' that it cannot be talked about as a single concept but with different spheres of her life. The term 'status', made popular by Ralph Linton (1936), is often used synonymously with 'role' and also interchangeably. Linton (ibid.) defined status as the 'polar position . . . in patterns of reciprocal behaviour; and role as a dynamic aspect of status. Status, which is conveniently used for all the rights and obligations which attach to an individual or a group, according to the customs of the society' (Redfield, 1972: 353), is 'a person's position relatively to that of others with whom he is in social relationships'(Mair, 1975 :10). In essence, status refers to who a person is, and role defines what such a person is expected to do. And, as the two terms are interrelated, these cannot be viewed independently. When we are talking about the status of women, it seems to be determined by various taboos attached to the women, and their 'child-bearing and child-rearing functions' (Majumdar and Madan, 1977: 147, 149); and also by the four determinants - actual treatment, legal status, opportunity for social participation, and the character and extent of work (Lowie, 1920). In his cross-cultural research, Martin Whyte (1978) rated fifty two different items that might be used to define the relative status of sexes -which includes such parameters as: which sex can inherit property, who has final authority over disciplining unmarried children, whether the gods in the society are male, female, or both, etc. The present paper is a brief account of the traditional aspect of polygyny and female status among the tribal societies of Manipur, with a quick look into the significant changes in the system.

\section{System of Ploygyny}

This paper aims to highlight the general system of polygyny that prevailed in the recent past in Manipur (India) and its impact on the relative status of co-wives. The state of Manipur, located at the northeastern most part of India, is a land of over two and half dozen different tribes who inhabit, sporadically, in the centrally located valley, and thickly in the surrounding hilly terrains. The tribes are either affiliated to one of the three linguistic groups (Naga Bodo, Eastern Naga and Kuki Chin) of the Tibeto-Burman Family. For instance, under the Naga Bodo group, among others, Kabui and Khoirao are included. Maram, Tangkhul, Maring, etc are within the Eastern Naga group. Aimol, Anal, Chiru, Hmar, Kom, Purum, Vaiphei, etc. are the tribal groups who belong to the Old Kuki subgroup of the larger Kuki-Chin. Likewise, Paite, Thadou, etc. are included under the Northern Chin sub group of the Kuki-Chin. The tribes have a more or less similar socio-cultural set ups. The traditional social system is strongly male-oriented, where the principle of organization, fundamentally is to the agnation of who governed residence, descent, access to economic resources, political affiliation and linkages through marriage. Within the strong framework of clan exogamy and tribe endogamy, the rule of bilateral cross-cousin (Mo $\mathrm{Br} \mathrm{Da}$ ) marriage is the most preferred and ideal one. The practice of sororate is prevalent more commonly than levirate, the later being reported at least, among the Kabui Nagas. Polygyny is permissible among the tribes, though monogamy is the general rule. The prevalence of polygyny in most of the tribal societies was known to be more prominent among the chieftains, clan heads, kings, great warriors and rich men. The motive behind the rule was varied - the primary objective being economic manifestation as social prestige of the polygynic men and sexual privilege. Among the Lusheis it 'is simply a matter of money and consequently it is almost entirely confined to the chief; for few others can afford to keep up two establishments' (Shakspear, 1975: 50). Stewart (1855) described the privileges of the Kooki kings for cohabiting with any of the married or single women in their villages who "may have as many wives as he likes or can keep' (c.f. loc cit., 194). The Meitei Kings, in the valley also had the same privilege of marrying any of the married or single women like his Kooki counterparts. However, the Tangkhul Nagas have a restricted norm to the rule of polygyny. Only persons who 
have no child to his first wife are sometimes allowed to marry a second wife with the approval of the first wife, and immovable properties for such a woman were apportioned by the family (Shimray, 1976: 20). But in many instances a good number of wives are married by the Tangkhul chiefs like those of his Konyak and Sema counterparts, who visited their wives by turn in their separate houses. In general, Naga warriors and wealthy persons married three wives and the village chief, five wives; however, Konyak chiefs could marry as many as fifty wives. The system of two wives norm was a, known practice among the Purum (Das, 1945), Maring (Das 1988), Zomi (Gougin, 1986) and Quoireng (Hodson, 1911). The practice, though allowed in the Purum society, was not a usual one, and f 'practised it is limited to two wives only and not more' (Das, 1945: 116). A Zomi chief also could acquire two wives at a time 'as a sign of despotism' and 'not as a customary practice' (Gougin, 1986: 33). Polygyny is also known to the people of Anal and Lamgang who possessed at least three wives at a time (Shakespear, 1975). The autocratic and arbitrary motive of Zomi chiefs to the rule of polygyny, however, differs from the concepts of social necessity, philanthropic idea and sexual urge of the Nagas (Shimray, 1985:179) that led to the occurrence of polygyny in their society.

Socially the chief and the persons in the public service should have enough manpower to manage the family and to maintain the status of the man. More males could not increase population and serve the public in feasts and in field work only more wives could produce more. Human nature also played its role. It is difficult to love only one woman. When one is in love with two girls, one desires to marry them both, so were the Naga heroes. From the philanthropic points of view, this system deserved our appreciation (ibid).

The system of polygyny in Manipur is partly in consonance with the r- strategy described above. Also the female contribution, here, relates to an indirect subsistence extent, likely to be benefited by more manpower of the offspring. Male sexual apatite and male status augmentation factors formed other explanations, but sex-ratio disparity was out of the scene. Though it functioned as an accepted institution, the mode of occurrence is not homogeneously distributed probably due to many socioeconomic factors. To the plain Meiteis, Chaki-Sirkar (1984:85) observed its more prevalence in urban areas than in the rural areas where the system 'is the exception rather than the rule.' She further observed that the stronger hold of polygyny among the urban elite 'is probably a result of the adoption of sanskritised values by women, which inculcate the indissolubility of the marital bond' (ibid, 202). Among the Naga Tribes of Manipur, Thomas Challan Hodson (1911: 94) noticed that 'polygamy (here refers to polygyny, as no system of polyandry is known in Manipur) is weakest in those groups in which the bachelors' hall is most definitely preserved'. The prevalence of concubine serves as one factor for the low occurrence of polygyny in the Maring society (Das, 1988:113). And, 'the Marings discourage polygamy by insisting upon the payment to the parents of the first wife of gifts of substantial value' (Brown, 1874, c.f. Hodson, op. cit., 94).

Under the system of polygyny, all wives are not given equal share of socio-sexual privileges and treatments. The ambivalence of man's perception of the co-wives' socio-sexual role or privilege is, by and large, controlled by the cultural values and norms of the society concerned. As such the first or the principal Maring wife has the highest position among other wives, and they are under the control of the major wife (Das, 1988:147). The non- major wives are also not entitled to maintain any separate house, unlike those of the Tangkhul Nagas and Meiteis. Moreover, legalization of a second wife to a Maring husband can be done only after the imposition of a fine on the second wife by the clan leaders (ibid.). The first Konyak wife of a village chief or rich or influential person of Nagaland, who could have as many as fifty wives like his Tangkhul counterparts in Manipur, - has the privilege of advising her husband and suggesting the girls who were likely to co-operate with her in family managements, which he (the husband) usually accepted (Shimray, 1985:179). Other than one major wife, a Meitei king unlike his Naga or Kuki counterparts 'may have three principal wives, with as many as one hundred and eight subsidiary partners . . The titles of the Raja's wives 
in order of precedence are - 1) Maharani, 2) Apanbi (which may mean either the preferred one or the one who rules), 3) Leimakhubi' (Hodson 1908:76).

Regarding the sexual right of the co-wives of a polygynous husband, either the principal wife or the most attractive one got more privilege than others. But it was not always true in some cases. The first wife of the Anal and Lamgang men were 'entitled to the company of her husband for five nights, the second for four, and the third for three (Shakespear, 1975: 153). The Tangkhul chiefs, like those of his Sema Nagas counterparts of Nagaland, visited their wives by turn who have separate houses and establishment, though the most attractive one has the privilege with the highest number of the chief's visit (Shimray op.cit: 178). The husband's attention to the several wives according to precedence was strictly regulated among the Meiteis, - 'the eldest getting twice the nominal share of the wife next below her' (Hodson, 1908: 77). Very often, owing to the unequal distribution of sexual privilege between the co-wives, husband-wives confrontation, and bitterness or jealousy between co-wives cropped up, thereby resulting in tension and unhappiness in the polygynous homes. When a husband procures another wife, or gives more sexual privileges to the new wife - a deep sense of anguish, loss of honour and mental disturbances of being humiliated etc, are felt by the older wife/wives. And it is a general phenomenon in many polygynyous societies ${ }^{(\mathbf{1})}$. To obliterate such abhorrent state of affairs different envisages are made, such as categorization of planned rotational period of sexual contact with the husband, maintenance and establishment of separate houses for each wives, and so on. Among the plain Meities, such bitter situations are less recognized between the sororal co-wives who almost always live together -though this type of union is quite rare (ManiBabu, 1991a). Generally, in such circumstances 'a wife may seek to express her sense of grievance at her husband's neglect by leaving him or blatantly engaging in extra-marital liaisons' (Epstein, 1979: 224). Such is the Meitei case where most marriages split up after the husband marries another woman, or general encouragement in setting up a matrilocal family by the polygynous wives with separate hearths (loc.cit.). C.B. Singh (1976) also found a high percentage of separation among the Thanga Meities because of the husband's second marriage (cf. Chaki-sircar, op cit.: 87-88). Frequently a Meitei woman who left her husband because of his second marriage may settle for the role of second wife to another man (ibid. 223).

The concubinage factor has posed as yet another domain in the network of polygyny. In a general sense, the tradition of concubinage is a pseudo-polygynous norm that seems to stem out mistakably from monogamous rule, since the concubines are not treated as co-wives of a man on the one hand, and they are generally not entitled to live in the same house with the principal wife and cannot be assigned to a family without ambiguity on the other. In a deeper sense, however, a concubine is also a sexual partner of a man who takes the place of secondary wife even though she usually has lesser relative status and prestige than those of the other co-wife/wives. In China and Japan, a man can have a concubine by way of purchasing, can bring her into his household, and since various Chinese laws and legal rulings defined their statuses, scholars think of these women as "secondary wives" and their children as members of the family (Goode 1975:47). In fact, the literal meaning of concubinage is the state of being cohabitation of a man and a woman who are not formally married to each other. J. Goody (1973) s'erves concubinage 'an attribute of monogamy rather than polygyny' (c.f. Das, 1988:113). Since it 'only involves sexual rights and not reproductive rights' (ibid.) there is a limited socio-sexual role in relation to other co-wives. Among the Meiteis, L.I. Singh (1963) took a woman's later marriage as concubinage. The female slaves of the Kukis of Lushei and Chin hills (particularly the southern tribes) are treated as concubines with respect to their masters (Shakespear, 1975; Carey and Tuck, 1976). The lack of legal status of the concubines and other lesser ${ }^{(2)}$ illegitimate wives often have disgrace impact on their children in regards to the inheritance of the father's property. More often, the legitimization of concubine is intimately connected with the social placement of her children in the respective kinship network. In general, the children of the true wife (the principal wife) are only considered as the legitimate heirs. In some instances, the children of concubines may be legitimized in case there are no lawful descendants. Among the Siyin tribe of Chin hills 'the children of concubines and lesser wives have no claim to 
any estate, and in the event of there being no issue by the chief wife, the brother of the deceased seizes property, but will feed and keep the wives and children of his brother' (Carey and Tuck, op cit.,209). A Maring Naga way is that the sons of the secondary wives may claim if there is no son by the major wife, and the criteria of inheritance right is on the basis of seniority (Das, $1988: 148$ ).

The socially approved system of marriage of the deceased brother's widow in some tribal groups of Manipur also escalates the prescribed rule of polygyny. Though social sanction of such a union prevails - the option, however, rests either on the widow or the deceased's brother to accept the union, which led to a system of what may be termed as 'conditional levirate'. Among the Tangkhul Nagas such a marriage was entirely of inclination and not compulsion (Hodson, 1911: 85). Hodson (ibid.) also happened to see, among many of the tribes of Manipur (which had been subject probably to the Kuki influence), the prevalence of the rule of junior levirate and not the senior one probably with the objectives, one, 'to serve the younger brother, if unmarried, the cost of a wife, and two, to make some use of a person, who would otherwise be a burden on the property of the deceased'. It is now clear that widows, whose natal households are not economically sound to pay back her bride wealth in case they want to come back to her family of procreation after a premature dissolution of marriage are but to accept yet the another affinal ties their deceased husband's family as a levirate spouse, an inherited widow. The excellence of such a tie is, however, not for the widows and her natal members only, but it is for the family of the deceased husband's also, because the bride wealth likely to be paid out at the time of their younger son's marriage is saved from being expended. Thus the system of levirate has its economic manifestation within the larger social value and contents. If a widow agrees to marry her deceased husband's brother she retains the rights of a formally-married wife among the Maring (Das, 1988). However her recognition as a legal wife is done through an imposition of a fine on her (called natukna) which symbolizes the recovery of bride price from the second wife. It is also seen among some tribes that if in cases where such marriages are compulsory, the younger brother refuses to marry the widow; he has to pay a fine, meithi. If the woman refuses to marry her husband's brother, her price (mangkat) is refunded, and she is returned to her people...' (loc. cit.). The concept of buying and selling, however, may be inconceivable because a father may not always force his daughter into a marriage against her wishes on the fact that bride wealth cattle, etc. would have to be returned in the event of a divorce. 'The principle that a marriage made legal by bride wealth is not dissolved even by the return of the marriage cattle' (Mair, 1975: 93) is widely seen among the tribal societies in Manipur.

The polygynic bearings upon bride wealth at the cost of the womens' economic asset are perceived by Goody and Tambiah (1973) as follows:

It has been argued that polygyny is found where women make a substantial contribution to productive activity, specially the cultivation. And that a measure of their contribution is the bride wealth that is paid for them at marriage (Goody, 1973:13). Bridewealth can neatly tie in with polygyny, with concubinage, with men of high status or great wealth 'acquiring' women of low status or in poor circumstances. When such propensities are carried to extremes there is a distinct flavour of 'purchasing' women, of maintaining 'harems' and the like. (Tambiah, 1973: 64).

However, it is pertinent to refer here that the system of bride wealth ${ }^{(3)}$ being a socially accepted norm among the tribes in Manipur, such as Paite, is never in the sense of buying or selling a human being, but it means several ideals and values like compensating the family for parting a daughter, symbolizing a new relationship between the two families and perpetuating relationship already in existence between the two families' (Khothang and Khenthong, 1976: 122). But among the tribes of the Chin Hills, Carrey and Tuck (1976:209) foresaw girls as the very precious possession to a father or a brother 'whom he sells to be wives at a very great profit'. And, the underlying motives of taking bride price in their societies are only to compensate the girls' parents for the loss of their daughter who was a great helper to them both in cultivation and household works (ibid, 189). The refinement of bride price by virtue of divorce or separation of a widow from her deceased 
husband's family due to the refusal of levirate-proposal, the system of taking fine from the younger brother who refuses to marry his deceased brother's widow, etc among the Nagas (Brown, 1870, c.f. Hodson, 1911: 207), may be seen as cultural manifestations to the balanced position of the females within the social crux of patriarchy. In the light of the polygynous rule, bride wealth bears socio-economic footing of a woman, the attachment of the ideal value, etc, which are being manifested through the (social) status of a polygynous husband who could afford heavy bride price for more than one wife. Hence, Sachchidananda's (1979) view of the bride price provision as an indication of higher status of tribal women is, however, justified by looking into the perpetuating rule practiced in Manipur.

\section{Polygyny and relative status of co-wives}

Women studies on status have unique importance in the societies having patriarchal framework of polygyny. The present discussion on the female status in view of the rule of polygyny, however, is no longer on the men-women controversy but between the principal wife and secondary wives, and between co-wives of a polygynous man. It is seen that the socio-sexual role of polygynous wives in these societies are varied, yet the principal wife gains a dominating status. In a polygynous marriage, the hierarchy of wives is unequivocal and the inferiority of the secondary wives is beyond dispute. The social backgrounds of the secondary wives are always inferior to the standing of the first wife, and the right and authority of the latter are unquestionable in the hierarchy of secondary wives within the household. Though a principal wife exclusively enjoys a social privilege over her fellow co-wives, it is not the case in the sexual domain. The advantages of a principal wife include a superior authority image over the secondary wives within the polygynous infrastructure, involvement of both sexual and reproductive rights, the right of the principal wife's children in inheritance with a legal status, etc. The aggressiveness of the first wife - who, in no case, would not like a compromise to her full privilege of socio-sexual share - has a psycho-social stance of the male -centered system of polygyny. This social institution, being a cultural manifestation of patrioriented society, is frequently susceptible by the husband's illegitimate sexual behaviour outside homes. The husbands are quite innocent of an analogic situation that if his wife happens to engage in it. Her husband's unbridled behaviour is likely to make the sole wife unhappy, and she is still not happy enough even when she gets the status of being a principal wife/first wife in the family. Her refusal to take that responsibility, of course, would not be viewed as unnatural, and is of more serious violations of role obligations than the refusal on the part of the secondary wives. A contrasting feature of cultural significances is the encouraging essence and spirit of the Tangkhul and Konyak principal wives to the arrangement of subsequent marital alliances - who, at the cost of their husbands' pivoted status (owing to it) can raise their heads high with pride as the principal wives in a polygynous or plural family. The statuses of co-wives in respect to their head wife and amongst themselves, thus, exist when they acknowledged acceptance of the social alliance that cropped up in the system, and indicates the roles they hope to play in it. Hence, a woman in a polygynous family does not enjoy the normal ascribed status and role expectations of an ideal proud wife (as does by her counterpart in a monogamous family) but burdened with a number of substatuses with roles that carry.

The socio-sexual privileges of a principal wife and her proclamation over the role as major wife are not only influenced but affected by her child- producing functions. The mothers of only daughters have a shaky position and could not have the social privilege of a principal wife (in the family). In such situations, social privilege and prestige of the principal wife seems to have transferred to another wife who could produce a son. Though sons of the co-wives have no inheritance right over the property they may have a claim, as in the Maring Naga society, if there is no son to the major wife. As prevalent among the tribal societies in Manipur, a Meitei wife's prestigious sex role is related to her child-bearing activity, and a childless and barren woman never reaches full status within the family as well as beyond (ManiBabu, 1991a). Naturally, the rights in genetricem by the husband over barren/issueless wife gives way to a loose tie over the rights in uxorem, that gives rise to divorce or to polygyny (ibid.). It is also seen that to bear children, especially sons, is important to 
a woman who establishes her position and prestige in her family of orientation and as more secure as that of the marriage rites. This is all the more important for the secondary wives, whose marriage is, very often, not marked by rites of any kind. Additional descendants prove irresistible to grandparents and, whatever the background of the mother, she usually established herself in the family because of the children, who are thus an invaluable adjunct to her, rather, doubtful status as wife. A woman's loss of privileges occurs not because of her sex but because of her bargaining position. If the senior wife in traditional society gained prestige from her role in the plural family, the vestiges of this have been won rather than in today's tribal society in Manipur; and it is generally assumed that any woman would prefer to be a sole wife, other things being equal.

\section{Present Scenario}

The system of polygyny in Manipur also shares some of the common features that are seen in other cultures in which such practice is allowed. These commonalities, as delineated by Kilbride (2003:300) include - division of work evenly among wives, fair practice of the visiting rule that requires the husband to visit each wife equally, separate houses and sleeping quarters for the wives, giving the first wife the most respected status of senior wife, etc.

The practice of polygyny in Manipur has witness marked changes owing to the impacts of western education, economic hardships, Christianity, etc. Christianity and education are the two important components which act as the powerful forces of social change. Here, social change refers to a process in which is discernible significant alteration in the structure and functioning of a particular social system. Various trends in social relationships and changes in values are included in the concept of modernization, in which a transformation of social, political and economic organization is involved. Both the impacts of modernization and westernization to the system of polygyny are discernible to its change. Introduction of western education and Christianity in Manipur by the British colonialists was at the middle of 1890. Conflicts between the tribal animists and the Christian preachers were common occurrences in the hill areas (ManiBabu, 1991 b; Singh, 1991). The two newly introduced systems are the most powerful agencies in making changes of the indigenous cultures and social values of the indigenous tribes. Obviously, these are responsible for the banishment of the traditional systems of slavery, head hunting, feasts of merit, bachelor's dormitory, and so on. Moreover, a similar impact is also on polygyny. The system of polygyny, which can be viewed as man's freedom of sex at the cost of his wealth and status, have been heavily influenced by the divine Commandment of the religious faith of Christianity such as one, 'Thou shall not commit adultery' (Exo. 20:14, cited in Shimray1985:190); two, 'if a man looks at a woman lustfully, he has already committed adultery with her in his heart' (Matt., 5:27. 28, cited in, ibid.). Such concepts of sexuality have significant impacts on the system of concubinage and on having more than one wife to a husband; thereby monogamy got a strong footing in the tribal society. Chaki-Sirkar (1984:202) finds lower incidence of polygyny among the plain Meitei population owing to the emotional ties between the spouses, duly encouraged by the social environment of modern education, economic hardship, and so on. Christianized and educated youths, now-a-days, are quite aware of the negative effects of the marriage system in the society. The pious Zomi Christians, 'strictly adhere to monogamy on the plea that polygamy is not conducive to a healthy family and creates misunderstanding and discord' (Gougin, 1986: 33-34). Owing to the impact of Western education - man's status, and prestige of being a husband of many wives have no place in the modern egalitarianism; and within the household, man's energies are somewhat diverted into household tasks which are meant ideally for the females. This has a meaning, rather, to the female status within the patriarchal framework of the tribal society.

\section{References}

Ahmed, J. 1986. "Polygyny and Fertility Differentials among the Yoruba of Western Nigeria." Journal of Biosocial Science 18(1):63-73.

Altmann, Stuart A; S. S. Wagner and Sarah 1977. Two Models for the Evolution of Polygyny. Behavioral Ecology and Sociobiology, 2(4): 397-410. 
Alvard, M. S. 1986. Polygyny as a Human Female Reproductive Strategy. Haliksai : UNM Contribution to Anthropology, 5:42-56.

Ansari, S. A. 1973. Economic Geography of Manipur, Imphal.

Arowolo, 0. 1981. 'Plural Marriage, Fertility and the Problem of Multiple Causation." In, Ware, H. (ed.) Women's Education and Modernization of the Family in West Africa. Australian National University, Department of Demography. (Changing African Family Project Series. Monograph No. 7).Pp. 112-33. Canberra, Australia.

Beals, R. L.; H. Hoijer; and A.R. Beals 1977. An Introduction to Anthropology (fifth edition). New York: Macmillan and Co.

Blumberg, R. L. and R. F. Winch 1972. Societal Complexity and Familial Complexity: Evidence for the Curvilinear Hypothesis. American Journal of Sociology. 77: 898-920.

Boserup, E. 1970. Women's Role in Economic Development. New York: George Allen \& Unwin.

Brown, R. 1874. Statistical Account of the Native State of Manipur and the Hill Territory under its Rule. Calcutta: Superintendent of Government Printing.

Burton, M. L. and K. P. Reitz 1981. The Plow, Female contribution to Agricultural Subsistence and Polygyny. Behaviour Science Research. 16: 275-305.

Carey, B. S. and H. N. Tuck, 1976. The Chin Hills.Vol.1 (First Published: 1896). New Delhi: Gian Publishing House.

Chaki-Sirkar, Manjusri. 1984. Feminism in a Traditional Society: Women of the Manipur valley. New Delhi: Shakti Books.

Coult, A. D., and R. W. Habenstein 1965. Cross Tabulations of Murdock's World Ethnographic Sample. Columbia, Missouri.

Dorjahn, V. R. 1959. 'The Factor of Polygyny in African Demography'. In, Bascom, W.R. and M. J. Herskovits (eds.) Continuity and Change in African Cultures. Pp. 87-142. Chicago: University of Chicago Press.

Dow, J. 1983. 'Women Capture as motivation for warfare'. In, Dyson-Hudson, R. and M. A. Little (eds.) Rethinking Human Adaptation: Biological and Cultural Models. Pp. 97-115. Boulder: Westview.

Eisenberg, J.F. 1966. The Social Organization of Mammals. Handb. Zool. 10: 1-92.

Ember, Melvin. 1974. Warfare, Sex Ratio, and Polygyny. Ethnology, 13 (2): 197-206.

Ember, M. 1984-85. Alternative Predicators of Polygyny. Behaviour Science Research, 19: 1-23.

Engels, F. 1985. The Origin of the Family, Private Property and the State (first published: 1884) Moscow: Progress Publications.

Epstein, A. L. 1979. 'The Case Method in the Field of Law.' In, Epstein,A. L. (ed.) The Craft of Social Anthropology. Pp. 205 - 230. Delhi: Hindustan Publishing Corpn.

Ford, C. and F. Beach 1951. Patterns of Sexual Behaviour. New York: Harper \& Row.

Garenne, M. and E. van de Walle 1989. "Polygyny and Fertility among the Sereer of Senegal." Population Studies 43(2):267- 83.

Goode, W. J. 1975. The Family (2nd Indian reprint). New Delhi: Prentice - Hall of India.

Goody, J. 1976. Production and Reproduction. London.

Goody, J. 1973. Polygyny, Economy and the Role of Women. In, Goody J. (ed.) The Character of Kinship. Pp.175-190. London: Cambridge University Press.

Goody, J. and S. J. Tambiah, 1973. Bridewealth and Dowry. Cambridge: Cambridge University Press.

Goswami, M. C. and H. Kamkhenthang 1975. Clan among the Paite. Bulletin: Department of Anthropology, Gauhati University. IV: 19 - 64.

Gougin, T. 1986. History of Zomi (2nd edition). Churachandpur: Zomi Press.

Grossbard, A. S. 1976. An Economic Analysis of Polygyny: the case of Maidugiri. Current Anthropology, 17: 701-707.

Grossbard, A. S. 1980.'The Economics of Polygamy'. In, Simon, J. L. and Ja Da Vanzo (eds.) Research in Population Economics. Vol.2. Pp. 321-350. Greenwich, CT: JAI Press.

Handwerker, W.P. 1986. "Natural Fertility as a Balance of Choice and Behavioral Effect: Policy Implications for Liberian Farm Households." In, Handwerker, W.P.and C. Boulder, (eds.) 
Culture and Reproduction: An Anthropological Critique of Demographic Transition

Theory, Pp. 90-111. Westview Press.

Hartung, J. 1982. Polygyny and the inheritancde of Wealth. Current Anthropology, 23: 1-12.

Heath, D. B. 1958. Sexual Division ogf Labour and Cross-cultural Research. Social Forces, 37: 7779.

Hodson, T. C. 1908. The Meitheis. London: David Nutt.

Hodson, T. C. 1911. The Naga Tribes of Manipur. Delhi.

Kamkhenthang, H. 1987. Possession of Kau spirit in Paite society. In, Singh R.K.S. (ed.), Methodology and Folklore Studies, Pp.189-198. Imphal: Manipur Folkore Society.

Karong, T. 1976. 'The Koms.' In, Singh, K. B. (ed.) An Introduction to Tribal Language and Culture of Manipur (7 tribes). Pp.62-78. Imphal: Manipur State Kala Akademi.

Khothang, T. J. and H. K. Khenthang. 1976. 'A Brief Introduction to the Language and Culture of the Paites (Teddim Chins)'. In, Singh, K. B. (ed.) An Introduction to Tribal Language and Culture of Manipur (7 Tribes). Pp.108-136. Imphal: Manipur State Kala Akademi.

Kilbride, P. L. 2003. 'African Polygyny - Family Values and Contemporary Changes'. In, Podolefsky, Aaron and Peter J. Brown (eds.) Applying Anthropology-An Introductory Reader. Pp.299-307. Boston: McGraw Hill.

Lack, D. 1968. Ecological Adaptations for breeding in Birds. London: Methuen.

Lee, G. R. 1979. Marital Structure and Economic Systems. Journal of Marriage and Family. 41:701-713.

Linton, R. 1936. The Study of Man. New York: Appleton-Century-Crofts.

Lowie, R. H. 1920. Primitive Society. New York.

Mair, Lucy 1975. An Introduction to Social Anthropology. (second reprint). Oxford: Clarendon Press.

Majumdar, D. N. and T. D. Madan 1977. An Introduction to Social Anthropology. (reprinted) Bombay: Asia Publishing House.

ManiBabu, M. 1991a. Meetei Family and the Status of Women: an Anthropological preliminary account. Manipur Today, XI (I): 47-52.

ManiBabu, M. 1991b. Education and Social Change among the Tribals of Manipur. Manipur Today, XI(3): 37-39.

Martin, M. K. and B. Voorhies 1979. Female of the Species. New York: Cambridge University Press.

Mead, Margaret 1950. Sex and Temperament in three Primitive Societies. New York: New American Library.

Mulder, M.B. 1989. Marital Status and Reproductive Performance in Kipsigis Women: Reevaluating the Polygyny-Fertility Hypothesis. Population Studies, 43(2): 285-304.

Murdock, G. P. 1949. Social Structure. New York: Macmilan.

Osmond, Marie W. 1965. Toward Monogamy: A Cross-Cultural Study of Correlates of Type of Marriage. Social Forces, 44: 6-16.

Pebley, A.R. and W. Mbugua. 1989. 'Polygyny and Fertility in Sub- Saharan Africa.' In, Lesthaeghe, R.J. (ed.) Reproduction and Social Organization in Sub-Saharan Africa, Pp. 338-64. Berkeley: University of California Press.

Pison, G. 1987. 'Polygyny, Fertility and Kinship in a Region of Sub- Saharan Africa.' In, The Cultural Roots of African Fertility Regimes, Proceedings of the Ife Conference, Population Studies Center. Pp. 16-27. February 25-March 1, 1987, Philadelphia: University of Pennsylvania,

Redfield, R. 1972. 'How Human Society Operates,' In, Shapiro, H. L. (ed.) Man, Culture and Society. Pp. 345-68. New York: Oxford University Press.

Sachchidananda, 1979. Changing Munda, New Delhi: Concept Publ. Co.

Shakespear, J. 1975. The Lushei Kuki Clans (reprinted). Aizawl: Tribal Research Institute.

Shimray, R.R. 1985. Origin and Culture of Nagas, New Delhi. 
Shimray, Y. K. 1976. 'Tangkhul Language and Culture'. In, Singh, K.B. (ed.) An Introduction to Tribal Language and Culture of Manipur (7 tribes). Pp. 1-30. Imphal: Manipur State Kala Akademi.

Sichona, F.J. 1992. 'The Polygyny-Fertility Hypothesis Revisited: The Situation in Ghana.' Carolina Population Center, Paper No. 92-01, University of North Carolina at Chapel Hill.

Singh C.B. 1976. 'Social Factors and Economic Development at Thanga Village of Manipur and a Short Social Philosophical Essay on Development'. Bulletin - Department of Anthropology Gauhati University, V: 20-47.

Singh, K. M. 1991. History of Christian Missions in Manipur and other Neighbouring States, New Delhi: Mittal Publications.

Verdon, M. 1983. Polygyny, Descent, and Local Fission: A comparative Hypothesis. Journal of Comparative Family Studies, 14: 1-22.

Verner, J. and M.F.Willson 1966. The influence of Habitat on Mating Systems of North American Passerine Birds. Ecol. 47: 143-147.

White, D.R. and M. L. Burton, 1988. Causes of polygyny: Ecology, Economy, Kinship, and Warfare. American Anthropologist, 90: 871 - 887.

Whyte, M. K. 1978. The Status of Women in Pre-industrial Societies. Princeton NJ: Princeton University Press.

Whiting, J. W. M. 1964. 'Effects of Climate on Certain Cultural Practices'. In, Goodennough, W. H. (ed.) Explorations in Cultural Anthropology. Pp. 511-544. New York: McGraw - Hill. 